Published in Human Ecology.

The original publication is available at www.springerlink.com from:

http://dx. doi.org/10.1007/s10745-005-7596-x

Author refereed postprint given below. 
Editorial Manager(tm) for Human Ecology - An Interdisciplinary Journal

Manuscript Draft

Manuscript Number: HUEC66R1

Title: Sustainable rangeland grazing in Norse Faroe

Article Type: Special Issue Manuscript

Section/Category:

Keywords: Historical ecology; Modeling; Rangeland Management; Norse Faroe.

Corresponding Author: lan A. Simpson,

Corresponding Author's Institution:

First Author: Amanda M. Thomson, BSc, PhD

Order of Authors: Amanda M. Thomson, BSc, PhD; Ian A. Simpson; Jennifer L Brown, MSc

Manuscript Region of Origin:

Abstract: The introduction of domestic livestock - particularly sheep - and rangeland grazing by Norse settlers to Faroe during the 9th century has generally been described as a major pressure on a sensitive landscape, leading to rapid and widespread vegetation change and contributing to land degradation. This view has, however, been developed without consideration of Norse grazing management practices which may have served to minimise grazing impacts on landscapes as well as sustaining and enhancing vegetation and livestock productivity. These alternative scenarios are considered using a historical grazing management simulation model with Faroese climate and vegetation inputs and given archaeological, historical and palaeo-environmental parameters. Three contrasting rangeland areas are investigated and, based on the maximum number of ewe / lamb pairs the rangeland could sustain, modeling suggests that utilisable biomass declined with the onset of grazing activity, but not to a level that would cause major changes in vegetation cover or contribute to soil erosion even under climatically determined poor growth conditions. When rangeland areas partitioned into what are termed hagi and partir are modeled, grazing levels are still within rangeland carrying capacities, but productivities are variable. Some rangeland areas 
increase biomass and livestock productivity's and biomass utilisation rates while other rangeland areas that were too finely partitioned were likely to suffer substantial decline in livestock productivities. Partitioning of rangeland is a likely contributor to long-term differentiation of landscapes and the relative success of settlements across Faroe beyond the Norse period. 


\title{
Sustainable Rangeland Grazing in Norse Faroe
}

\author{
Amanda M. Thomson', Ian A. Simpson², Jennifer L. Brown
}

The introduction of domestic livestock - particularly sheep - and rangeland grazing by Norse settlers to Faroe during the $9^{\text {th }}$ century has generally been described as a major pressure on a sensitive landscape, leading to rapid and widespread vegetation change and contributing to land degradation. This view has, however, been developed without consideration of Norse grazing management practices which may have served to minimise grazing impacts on landscapes as well as sustaining and enhancing vegetation and livestock productivity. These alternative scenarios are considered using a historical grazing management simulation model with Faroese climate and vegetation inputs and given archaeological, historical and palaeo-environmental parameters. Three contrasting rangeland areas are investigated and, based on the maximum number of ewe / lamb pairs the rangeland could sustain, modeling suggests that utilisable biomass declined with the onset of grazing activity, but not to a level that would cause major changes in vegetation cover or contribute to soil erosion even under climatically determined poor growth conditions. When rangeland areas partitioned into what are termed hagi and partir are modeled, grazing levels are still within rangeland carrying capacities, but productivities are variable. Some rangeland areas increase biomass and livestock productivity's and biomass utilisation rates while other rangeland areas that were too finely partitioned were likely to suffer substantial decline in livestock productivities. Partitioning of rangeland is a likely contributor to long-term differentiation of landscapes and the relative success of settlements across Faroe beyond the Norse period.

Key Words: Historical ecology; modeling; rangeland management; Norse Faroe.

School of Biological and Environmental Sciences, University of Stirling, Stirling FK9 4LA, Scotland, U.K.

${ }^{1}$ Present address: Centre for Ecology and Hydrology (Edinburgh), Bush Estate, Penicuik, Midlothian EH26 0QB, Scotland, U.K.

${ }^{2}$ Corresponding author: i.a.simpson@stirling.ac.uk 


\section{INTRODUCTION}

The introduction of domestic livestock and north-European grazing management practices by Norse settlers to north Atlantic pristine landscapes (Landnám - Faroe during the $9^{\text {th }}$ century; Iceland ca. 872 A.D. and Greenland 895 A.D.) has been portrayed as a major environmental impact introducing long term trajectories of landscape change reaching to the present day. Palynological data from Faroe have been interpreted as indicating rapid and widespread replacement of woodland shrub communities and herb rich parklands by species poor, low productivity acid heathland and blanket bog as a result of grazing livestock (Hannon et al., 2001; Hannon and Bradshaw, 2000; Jóhansen, 1981). Such observations are seen as fitting a pattern observed elsewhere in the north Atlantic region. In Iceland dramatic decline in woodland cover heralded the loss of some $40 \%$ of topsoils in Iceland (Buckland et al., 1991; Hallsdóttir, 1987; Friðriksson, 1972; Thorsteinsson et al., 1971), while in Greenland deforestation of birch and willow occurred with related soil movement (Fredskild, 1992; 1988; Jakobsen, 1991; Sandgren and Fredskild, 1991). Recent research from Iceland has, however, started to suggest that grazing regimes introduced with colonisation and settlement were not uniformly damaging to the landscape and that some rangeland management systems may have minimised the environmental impacts of grazing livestock. In early common land summer grazing areas in the south of Iceland model-based evidence suggests that there was sufficient biomass production to support the numbers of livestock defined in historical documentary sources. Furthermore, with careful assessment of the start and end of growing seasons mediated by Commonwealth period (930 - 1262 A.D.) legal traditions (documented in Grágás), land degradation could have been avoided (Simpson et al., 2001). Similar research on early winter grazing areas, inherently susceptible to grazing damage because of the seasonal low in biomass productivity, has also suggested that adaptive grazing management may have taken place in some locations, significantly reducing possible degrading impacts of grazing livestock (Simpson et al., 2004). 
Despite emerging evidence of the significance of management in limiting or preventing degrading landscape impacts associated with domestic livestock during colonisation and settlement, quantitative assessments of the pressures that grazing livestock may have brought to north Atlantic pristine landscapes are only beginning to be attempted (Thomson, 2003; Thomson and Simpson, in press a). This paper seeks to widen the debate on historical grazing pressures on north Atlantic landscapes by investigating for the first time pressures introduced by the commencement and development of extensive Norse grazing practices in Faroe where sheep were likely to have been the main domesticates (Arge et al., in press). In doing so, we seek to assess the current view that introduction of domestic livestock brought major pressures to a sensitive landscape and were of a nature that could have resulted in rapid, degrading, vegetation change and possible erosion. If this hypothesis is to be supported we would expect livestock numbers to be high in comparison to the carrying capacity of the rangelands used with no evidence of landscape organisation to alleviate grazing impacts. Conversely, to refute the hypothesis we would expect livestock numbers to be low in comparison to the carrying capacity of rangelands with evidence of management ensuring the maintenance of vegetation productivity and soil stability.

To test hypothesis validity we undertake quantitative assessments of carrying capacities, utilisations and management organisation of three rangeland grazing areas during Norse colonisation and settlement of Faroe (from early Norse to late Norse, alternatively termed the Viking age to the high medieval period $-9^{\text {th }}$ century to $13^{\text {th }}$ century A.D.), at Leirvík on Eysturoy, at Sandur on Sandoy and at Hov on Suðuroy. Assessment is made through application of a historical rangeland management model, Búmodel, based on productivities of different vegetation classes and sheep livestock grazing preferences (Thomson and Simpson, in press b). Four key outputs from the model are used in this paper to indicate carrying capacities and rangeland utilisation efficiencies. These are the maximum number of ewe (sheep) and lamb pairs / ha the rangeland grazing area could carry 
without resulting in extensive vegetation loss, annual live body weight produced by the grazing area (kg/ha), average annual utilisable biomass (dry matter $\mathrm{kg} / \mathrm{ha}$ ) and annual cumulative vegetation utilisation by livestock (\%). Data are presented for the three rangeland areas modeled as preLandnám (before Norse settlement giving vegetation productivities only) as Landnám with no grazing regulation (conditions at the beginning of settlement) and as Landnám once a hay field and arable area had been enclosed (the infield or home field). Further analyses from each of the three areas are presented for a subsequently emerging management regime, interpreted from early historical sources as late Norse, which partitioned the rangeland into a number of grazing areas, the hagi and partir pastures. The paper concludes by considering the modeled grazing pressures in relation to evidence of landscape change and to changing social demands on rangeland areas.

\section{HISTORICAL ECOLOGY CONTEXT}

The Faroe archipelago comprises 18 islands midway between Iceland and Scotland, centred on $62^{\circ}$ $\mathrm{N} 7^{\circ} \mathrm{W}$ (Figure 1), and are mainly composed of basalts, producing steep sided islands that are deeply incised by fjords on the eastern side. The climate is mild for the latitude (due to the presence of the North Atlantic Drift current) and highly oceanic, with a mean winter temperature of $3-4{ }^{\circ} \mathrm{C}$, and a mean mid-summer temperature of $9-10^{\circ} \mathrm{C}$. Annual precipitation is high $(800->3000 \mathrm{~mm})$, with twice as much falling in winter as in summer. Topographic variation can produce considerable variations in local climate. The soils at lower elevations (below ca. 300m) generally have a thick organic layer, are very moist and strongly acidic, and are dominated by heaths. Soils at higher elevations are more minerogenic and less acidic; the dominant vegetation types on these soils are grasslands and grassy moors. Mires have developed in the bottom of valleys, in depressions and other wet areas (Fosaa, 2001). Mountain tops and plateaus are covered in sparse alpine vegetation and/or mosses. There are no areas of natural woodland in the Faroes, although isolated stands of 
Salix phylicifolia and Juniperus communis nana scrub exist in some locations (Hansen and Johansen, 1982).

Figure 1 located here

Prior to Norse settlement there is written evidence to suggest that Celtic hermits may have occupied the islands (Teirney, 1967) and pollen data together with a tradition of early, or Celtic, field systems in some locations has been interpreted as evidence of pre-Norse arable activity (Arge et al., in press; Simpson and Guttmann, 2002). Furthermore, radiocarbon measurement of sheep / goat bone from a

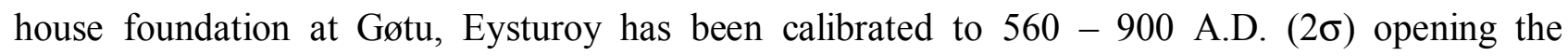
possibility of a pre-Norse domestic grazing regime (reported by Hannon and Bradshaw, 2000). Much of this evidence is however contested, with a more certain and rapid Norse settlement occurring from the early to mid 9th century. Settlement and agriculture in the Faroes are confined to narrow strips of flat land along the sides and heads of the fjords. The pre-modern settlement pattern was based on townships, or communes, which consisted of one or more farms (býlingar), often associated with a church, and enclosed within an area called the bøur (also called bygðir) that included cultivated infield and uncultivated outfield (Arge, 1997). Beyond the bøur, the rangeland was communal and included shieling activity, where milking livestock were grazed in the summer months, as indicated by eighteen locations with the place name cergi, considered incorporated into the Norse language from Gaelic during the $9^{\text {th }}$ century (reported by Arge et al., in press). Archaeological evidence from Argisbrekka on Eysturoy suggests that that the shieling system was phased out during the $11^{\text {th }}$ and $12^{\text {th }}$ centuries (Mahler, 1991). Early rangeland areas were also subdivided into hagar; each hagi belonged to one bøur and was in turn divided into partir (sing. partur) with divisions maintained by shepherding rather than any physical boundary (Brandt, 1996). Elements of this grazing system are suggested in the Seyðabrcevið or Sheep Letter, a document 
describing Faroese agricultural regulations dating from 1298 A.D. The Sheep Letter also recommends the use of set stocking rates:

'The number of sheep to be kept on an area of pasture land shall be the same as it was in previous times, unless men see that it can accommodate more. In that case they are to have as many sheep as they agree on, and each man is to keep a flock proportionate to the size of his pasture. The same applies to other forms of livestock, cattle or horses.'

This suggests that there may already have been a well-established arrangement, known as skipan, between flock size and hagi - partir pasture area by the end of the $13^{\text {th }}$ Century, although it is not until the early modern period that clear evidence for the hagi - partir system is found.

\section{METHODS}

\section{Study areas}

Three rangeland areas, all associated with settlements dating back to the Landnám (settlement) period, geographically representative of rangeland areas in Faroe, and defined by existing historical boundaries and recent archaeological and documentary studies of early settlement distribution (Arge, et al., in press) are investigated in this paper. These rangelands belong to Leirvík on Eysturoy (ca. 1,040 ha), Sandur on Sandoy (ca. 4,760 ha) and Hov on Suðuroy (ca. 1,060 ha) (Figure 1). Digital terrain models of each area were created by digitising contours from raster images of 1:20,000 topographic maps using Erdas Imagine 8.5 and ArcInfo 8.2. The known hagi / partir and bøur boundaries were also digitised from this source.

Leirvík. There are three býlingar - um Á, við Garð and á Toftanesi - at Leirvík. Archaeological excavations have recorded a Viking-Age settlement at á Toftanesi and medieval settlement remains 
dating to the $12^{\text {th }}-14^{\text {th }}$ Century ( $i$ Uppistovubeitinum) near the site of við Garð (Stumman-Hansen, 1988; Arge, 1997). Palynological and palaeo-entomological evidence from á Toftanesi indicates a mainly open landscape with a largely pastoral economy during the settlement period (Edwards et al., 1998). There is some evidence of over-grazing, as grass pollen is replaced by the pollen of less palatable plants such as sedges, thyme and sorrel, although grass pollen and charcoal increase again later. Little wood or shrub pollen was found, suggesting that if birch or juniper scrub were locally present they were at some distance from the settlement, and may have been protected from, or were inaccessible to grazing animals. It has been argued by Edwards et al. (1988) that the absence of a hay component in the insect fauna may indicate pastures at Leirvík were sufficiently productive at Landnám that winter hay-feeding of livestock was unnecessary, although more recent palaeoecological work (Vickers et al., in press) and soils-based evidence of an identifiable early home field indicate that hay production was likely (Adderley and Simpson, in press).

Sandur. At Sandur three original holdings have been identified - Úti á Bø, Norðri á Bø and á Sondum - although they may have been divided later into smaller farms (Arge et al., in press). An cergi place name, indicating a sheiling site, is located in the rangeland area some $8 \mathrm{~km}$ north-west of Sandur. Excavations since the $19^{\text {th }}$ century have uncovered at least five successive church construction phases, with the earliest $11^{\text {th }}$ century construction resembling a Norwegian stave church; more recently an extensive Viking Age burial ground has been excavated just south of the church (Arge, 2001). Well preserved animal bone and early medieval artefacts have eroded out of the sandy cliff near the modern village of Sandur for some time, and during the investigations at the church and churchyard soil phosphate mapping revealed a major concentration of activity on the crest of the ridge above the eroding bone deposits. Following major storm damage in 1999-2000 the Faroese National Museum under the direction of Símun Arge carried out a small scale rescue excavation of part of the erosion face. This revealed well stratified deposits with excellent bone preservation and also yielded Viking Age artifacts and basal $9^{\text {th }}$ century radiocarbon dates, 
indicating that this is the earliest Viking site so far discovered in Faroe. Recent palynological evidence from the nearby Gróthúsvatn suggests that the landscape seen today is similar to the landscape at settlement with limited tree populations, extensive areas of grass-sedge communities and more localised areas of blanket bog (Lawson et al., in press).

Hov. Place name evidence suggests four býlingar at Hov - Í Trøđini, Viđ Gard, Á Brekku and Á Brugv - with the location prominent in the Fareyinga Saga describing events in the decades before and after 1000 A.D., although written after 1200 A.D. (Arge, 1991). The Ergidalur shieling site is located in rangeland some $4 \mathrm{~km}$ west of Hov (Dahl, 1970). Two pollen cores have been published for this area, one from a bog infill of a former lake and one from an open section, both below $100 \mathrm{~m}$ near the outlet of the Hovsá river (Jóhansen 1981). Landnám at Hov is indicated by the appearance of Plantago lanceolata pollen between 850 and 900 A.D., although Hordeum pollen does not appear until the medieval period (between 1060 and 1385 A.D). The pre-landnám cover of tall, herb-rich wet meadow vegetation in the vicinity of the cores is thought to have rapidly disappeared, presumably through summer grazing. The short-lived increase in Rumex acetosa pollen after landnám possibly suggests a period of over-grazing which was then brought under control, as Rumex is unpalatable to sheep.

\section{Grazing simulation modeling}

Historical environmental simulation modeling provides a means of setting multiple sources of environmental and archaeological information about an area within a framework representing the real-life human-environment system. A simulation model that incorporates both space and time as dimensions allows information derived from point sources (palynological, geomorphological and archaeological excavation data) to be extrapolated across a landscape, thus enabling the investigation of spatial and temporal patterns of resource utilisation. A grazing management simulation model, Búmodel, has been developed and validated for pre-modern Icelandic rangelands 
(Figure 2; fully described in Thomson \& Simpson, in press b, and available at http://www.sbes.stir.ac.uk/research/environmental modelling/) and has proved a valuable tool for investigating the impact of grazing management decisions upon sensitive landscapes in Iceland (Thomson, 2003; Thomson and Simpson, in press a). Búmodel uses vegetation, climate, livestock, and management inputs to predict patterns of vegetation biomass availability and removal by grazing livestock in a landscape on a monthly basis. The model estimates rates of vegetation utilisation, which can be used to assess which areas in the landscape are vulnerable to over-grazing, and consequently susceptible to vegetation change and soil erosion.

\section{Figure 2 located here}

Assessment of key elements within Búmodel indicates that its application is appropriate to Faroe, although the climate of Faroe is much wetter than that of Iceland and exhibits less annual temperature variation. Precipitation has a greater influence upon vegetation growth, and mean winter temperature a lesser one, as long spells of sub-zero temperatures in winter are rare. Analysis of the meteorological observation records for sites throughout the Faroes (Danish Meteorological Institute, 1998) indicates that total monthly precipitation is negatively correlated with mean monthly temperature but the strength of this relationship is spatially variable. It is assumed that precipitation is not limiting to growth for rangeland vegetation. Climate calibration allows growth scenarios to be developed within Búmodel, emphasizing the role of growing season length (when the mean monthly temperature $>5^{\circ} \mathrm{C}$ ) and summer temperature in influencing vegetation production. Relationships between climatic parameters and rangeland vegetation production in the Faroes have not been quantified, so it has been assumed that the scenarios developed for Iceland (named good, average and poor growth scenarios for Faroe) are also applicable in the Faroes (Table I). This assumption is more justifiable for the summer months (when temperatures are similar in 
both locations due their oceanic climates), more caution is needed for the winter months (when Iceland is much cooler).

\section{Table I located here}

The native Faroese sheep breed is very similar to the Icelandic, both being breeds of the Northern European short-tailed race of sheep, and both originating from the livestock introduced by the Norse settlers at Landnám. Live weights for sheep in the past were lower than in the present day and can be estimated from the zooarchaeological evidence (McGovern, pers. comm.). The range of potential sheep body weights fall within the scope of Búmodel and lamb growth rates and plant dietary preferences are similar.

Plant species and community composition on the grazing areas are very similar to those found in Iceland (Fosaa 2001; McMullen pers. comm.), although Nardus stricta and Potentilla erecta are more widespread, possibly due a combination of heavy grazing and the wet climate (Fosaa 2001). Thus Búmodel vegetation categories of hayfield, grassy heath, dwarf shrub heath, moss heath, bog/mire and sparsely vegetated land - categories designed for use in grazing studies - are used unaltered in the Faroese version of the grazing model. Búmodel riverine and birch woodland vegetation categories do not appear to have any contemporary equivalents in Faroe, but are relevant when reconstructing Landnám vegetation cover (Jóhansen, 1981).

Testing of the model in Faroe considered utilisable biomass productivities for five locations in the Sandur study area compared against sample measured productivities in the same locations and gathered on $9^{\text {th }} / 10^{\text {th }}$ June 2005. Comparison indicates that measured values are generally within 1 sd of the modelled values, although at the lower end of the modelled values (Figure 3). This can be explained by an unusually cold and dry spring and by a continuous low level of grazing during the 
winter and spring. Preliminary modelling also considered maximum ewes and lambs / ha for sample areas, predicting a range of between 0.4 and 1.3; this stands comparison with a published figures of ca. 0.35 / ha medium slaughter sheep / ha, noting that some small island locations had much higher values, (Brandt, 1984). Although the measured values are not from experimental plots or animal productivity experiments, they do give added confidence in the application of the model to Faroe.

\section{Landscape reconstruction: environment and management.}

Present-day distributions of vegetation were used as a base-line with Búmodel classes mapped using orthophotographs of Leirvík and Sandur (Faroes Data Store 2003; scale 1:20,000), and colour aerial photographs of Hov (scale 1:15,000; Matrikulstovan 2000); all photographs were taken in the summer of 2000. Systematic air photograph and field observation of the study sites permitted ecological relationships to be established, including the position of the periglacial boundary controlling distribution of alpine vegetation (Humlum and Christiansen 1998). Representative ground-truthing of the air photograph interpretations was undertaken for the Sandur grazing area with a hundred random points generated using the Random point generator v. 1.27 in ArcView GIS 3.2. These points were located in the field using a GPS 72 and the vegetation present at each point recorded according to the Búmodel categories in June 2005. A 89\% map accuracy is estimated, with the main errors being an overestimation of moss heath relative to sparsely vegetated land and grassy heath relative to bog. Of note is recent and continuing introduction of open drainage ditches with consequent succession from bog communities to grassy heath communities on degrade peat.

Palynological data (Jóhansen, 1981; Edwards et al., 1998; in press; Hannon et al., 2001; Hannon and Bradshaw 2000; Lawson et al., in press) provided indication of vegetation classes pre-Landnám and during the Norse period, and where appropriate were used to adjust the maps of present day land cover. In the absence of rangeland pollen data from Leirvík the mapped present day cover was 
used and is justified in that recent pollen analyses in other parts of Faroe indicates only minor variances in vegetation cover from the settlement period. At Sandur quantitative pollen data from the Gróthúsvatn catchment, within the rangeland grazing area indicates a ca. $12.5 \%$ decline in heath pollen and a parallel increase of ca. $14 \%$ in Poaceae pollen between Landnám and the present day; there is evidence of only minor changes pollen associated with other vegetation communities (Lawson et al., in press). As the present day grassland hay meadow area covers $12.5 \%$ of both the Gróthúsvatn catchment and the Sandur grazing area, the major spatial change in vegetation cover from Landnám to the present day is interpreted as being from heath to grassland in lowland areas. Palynological data from two recent cores at Hov are more complex and indicate differences between infield and rangeland locations (Edwards et al., in press). However, quantitative pollen data from between Landnám and the present day are generally within the range expected for the different Búmodel vegetation categories derived from air photograph interpretation. Exceptions are a higher than expected Cyperaceae occurrence and marked variances in herbaceous species. The reconstructed vegetation maps, showing mosaics of grassland and heathland covering much of the rangelands with rocky outcrops and mountain plateaus only sparsely vegetated, were superimposed on digital terrain models and divided by a fishnet of 5ha cells at Leirvík and Hov, and 25 ha cells over the larger Sandur grazing area, individually covering the rangelands for model analyses.

Model simulations were undertaken that assessed the maximum number of livestock (ewe and lamb pairs / ha) that could have been sustained without land degradation for each management type under different growth scenarios and the patterns and efficiencies of vegetation utilisation that develop under different Norse management scenarios (Table II). An annual $40 \%$ utilisation threshold is used for the grassy heath, moss heath and sparsely vegetated communities, a threshold of $15 \%$ for dwarf shrub heath and a 35\% threshold for bog/mire (RALA, 1978-1981). Above these levels vegetation is defoliated at a level affecting reproduction and survival, leading to loss of cover. 


\section{RESULTS AND DISCUSSION}

\section{Vegetation productivities before Landnám}

Immediately prior to Landnám, vegetation covers distributed across the three rangeland areas are considered to include grassland, grass - heath mosaics, dwarf shrub heath, moss heath, riverine vegetation, wet meadow vegetation and bog, together with sparse vegetation cover and ungrazable areas. These vegetation covers follow altitude and soil wetness gradients, with grassland and grassland heath mosaics dominant and occupying mid-slope positions (indicated in Figures 4a, 5a and 6a). Utilisable biomass values (kg dry matter / ha) provide a base-line from which to assess the impact of different early management types, and across the whole rangeland and under average growth conditions utilisable biomass at Leirvík is predicted to average 1290 (sd. 374) with a monthly average range of 664 (April) to 2618 (July) (Table III). Predictions of utilisable biomasses under good and poor growth scenarios are 1556 and 1012 respectively. At Sandur the average utilisable biomass is predicted to be 1575 (sd. 461) with a monthly average range of 871 (April) to 3265 (July). Under good and poor growth scenarios utilisable biomass is predicted to be 1834 and 1175 respectively. At Hov the average utilisable biomass is predicted to be 1570 (sd. 467) with a monthly average range of 801 (April) to 3251 (July). Here, under good and poor growth scenarios utilisable biomass is predicted to be 1890 and 1224 respectively. There are marked differences in utilisable biomass through the growing season at both locations, but it is of note that there is still substantial amounts of utilisable biomass during the winter months even at the highest altitude and under poor growth conditions.

Figure 4 located here 
Figure 5 located here

Figure 6 located here

\section{Table III located here}

These results highlight significant differences between rangeland grazing areas and indicate that differences in grazing land quality may have been a factor in influencing Landnám settlement location. The results indicate that the more southerly islands in the archipelago had greater rangeland vegetation productivities with the potential to hold a greater number of livestock and that this may have been a factor in the success and diversification of settlements after Landnám. The results further suggest that rangelands held sufficient utilisable biomass to allow grazing by domestic livestock, sheep in particular, throughout the winter under most climatic conditions. This would serve to reduce pressure on valuable hay resources during the winter months which could be entirely given over to cattle and to milking cows. Rangeland areas at Landnám offered considerable biomass resources and gave good opportunity for an economy based on domestic livestock to thrive; critical differences to the success, failure and resilience of such activity would have rested on the extent and management organisation of the available rangeland area.

\section{Sheep grazing capacities and efficiencies at Landnám}

With initial introduction of unregulated grazing at Landnám and prior to bøur enclosure, the maximum sheep grazing capacity at Leirvík under average growth conditions is predicted to be 0.8 ewes and lamb pairs / ha (estimated 832 ewes and lamb pairs) with live body weight productions of $28.2 \mathrm{~kg} /$ ha (Table III). The average utilisable biomass is predicted to be $1245 \mathrm{~kg}$ dry matter / ha, reduced slightly from the pre-Landnám level in response to grazing pressures. The spatial 
distribution of utilisable biomass across the rangeland area is indicated in Figure $4 \mathrm{~b}$ and shows a broad variance with altitude; highest annual average biomasses are evident along the coast, declining with altitude and on the steepest of slopes. The annual average cumulative utilisation rate across the rangeland of this stocking level is predicted to be $17 \%$ with the spatial distribution of utilisation, partially reflecting stock grazing preference, indicating that grassy mid-slope positions come under the greatest grazing pressure although not exceeding threshold utilisation rates (Figure 4c). With introduction of the bøur area, and the consequent reduction in rangeland grazing area, the maximum sheep grazing capacity under average conditions is 0.55 ewe and lamb pairs / ha (572 ewe and lamb pairs); live body productions also fall to $18.7 \mathrm{~kg} / \mathrm{ha}$. Under this scenario the annual average cumulative utilisation rate is $14 \%$ with an average utilisable biomass of $1182 \mathrm{~kg}$ dry matter / ha. Under good growth conditions the maximum number of sheep that could be supported is 0.9 ewe and lamb pairs (936 ewe and lamb pairs with $1419 \mathrm{~kg}$ dry matter / ha and 15\% annual cumulative utilisation rate). Under poor growth conditions 0.4 is the maximum ewe and lamb pairs / ha for the grazing area (416 lamb and ewe pairs, with $924 \mathrm{~kg} /$ ha dry matter; 18\% annual cumulative utilisation rate).

At Sandur the maximum sheep grazing capacity under average growth conditions is predicted to be 1.4 ewes and lamb pairs / ha (6664 ewes and 1000 lambs) with a live body weight production of $72.3 \mathrm{~kg} /$ ha (Table III). The annual average cumulative utilisation of this stocking level is predicted to be $31 \%$ with an average utilisable biomass of $1484 \mathrm{~kg}$ dry matter / ha; the sheiling location is amongst the most intensively utilised areas. The spatial pattern follows that of Leirvík (and also Hov) with an altitudinal decline in productivity and utilisation rates (Figures $5 \mathrm{~b}$ and $5 \mathrm{c}$ ). With the bøur introduced, the maximum sheep grazing capacity under average growth conditions is predicted to be 1.3 ewe and lamb pairs / ha (3807 ewes and 1000 lambs) with similar live body weight production of $73.0 \mathrm{~kg} / \mathrm{ha}$. Under good growth conditions the maximum number of sheep / ha is predicted to be 1.8 ewes and lambs (8568 ewes and 1000 lambs) with an average utilisable biomass 
of $1790 \mathrm{~kg}$ dry matter / ha and an average annual cumulative utilisation rate of $26 \%$. Under poor growth conditions these values are 0.75 ewes and lambs/ha (2142 ewes and 1000 lambs), an utilisable biomass of $1135 \mathrm{~kg}$ dry matter / ha and an average annual cumulative utilisation rate of $31 \%$

At Hov, the maximum sheep grazing capacity under average growth conditions is predicted to be 1.3 ewes and lamb pairs / ha (1,378 ewes and lamb pairs) with a live body weight production of $63.4 \mathrm{~kg} / \mathrm{ha}$ (Table III). These maximum livestock numbers are predicted to have a $32 \%$ annual average cumulative utilisation rate of available biomass across the rangeland grazing area which, like Leirvík, would have had the effect of slightly reducing the pre-Landnám average utilisable biomass to $1486 \mathrm{~kg}$ dry matter / ha. Spatial patterns of utilisable biomass are predicted to be more complex in comparison with Leirvík, although again there is a trend of decline in productivity with altitude (Figure 6b). Annual cumulative utilisation spatial patterns are also complex with pressures greatest on grassy heaths and heaths, and there is increased grazing pressure in the shieling location (Figure 6c). Bøur areas would, however, have been quickly established and enclosed to provide areas for hay and cereal production. With this reduced rangeland grazing area the maximum sheep grazing capacity under average growth conditions is predicted to be 1.2 ewe and lamb pairs / ha (1272 ewe and lamb pairs) with a live body weight production of $58.5 \mathrm{~kg} /$ ha. Under good growth conditions the maximum number of sheep the Hov grazing area could support is predicted to have been 1.6 ewe and lamb pairs / ha (1696 ewe and lamb pairs) with an average utilisable biomass of $1803 \mathrm{~kg}$ dry matter / ha and an average annual cumulative utilisation rate of $26 \%$. Under poor growth conditions these values are 0.75 ewe and lamb pairs / ha (795 ewe and lamb pairs), an utilisable biomass of $1177 \mathrm{~kg}$ dry matter / ha and an average annual cumulative utilisation rate of $27 \%$. 
Flock sizes of between 30 and 50 to a household, with sheep providing milk, wool and meat, are typical of subsistence level economies in the historic north Atlantic region (see for example Melsteð et al., 1990). Modeling suggests that the maximum numbers of livestock the three rangeland areas could support without causing major landscape degradation is generally well within subsistence levels of the associated settlements. Indeed it is likely that rangelands could have supported a livestock grazing regime that yielded surplus without landscape degradation, with Sandur particularly advantaged because of its location and large rangeland grazing area. Even when good quality rangeland was enclosed to form the bøur subsistence level flock sizes could still be easily maintained, although live body weight values per ha decline implying less animal productivity. Flocks may have been harder to maintain under poor growth conditions, but this would have been offset by improved hay productivities derived from the bøur. The small but consistent modeled decline in utilisable biomass observed moving from pre-Landnám vegetation cover through to the introduction of the bøur indicates a limited impact on vegetation with the introduction of grazing livestock. This implies possible changes in species compositions, although percentage annual cumulative utilisation values remain below levels likely to result in large community changes in vegetation cover or in the exposure of soils resulting in erosion. The results suggest therefore only a limited pressure on the landscape from the introduction of sheep grazing.

\section{Hagi - partir rangeland partition}

Modeling of utilisable biomass production, live body weights and annual cumulative utilisation for hagi - partir areas in each of the three study locations indicates varying rangeland consequences with key trends summarized in Table IV. At Leirvík in four of the six hagi, vegetation productivity under average conditions stabilise or improve slightly relative to productivity found in the rangeland with bøur scenario (ranging from 1196-1215 kg dry matter / ha). Productivities do not however return to pre-Landnám levels; the same findings emerge when modeling good and poor growth scenarios. Annual cumulative utilisation rates vary between $16 \%$ and $21 \%$ in the different 
hagi's under average growth conditions, and although higher than utilisation rates in pre- hagi partir rangeland, are still well within sustainable utilisation rates. Of key significance are the live body weights ( $\mathrm{kg} / \mathrm{ha}$ ) from hagi - partir rangelands which vary from $22.6-28.5$ with average growth conditions. These live body weights are a significant increase on live body weights prior to the introduction of hagi-partir, indicating a greater efficiency in the use of utilisable biomass, and are also paralleled under good and poor growth conditions. At Sandur nine out of sixteen hagi partir have vegetation productivity improved in relation to productivity in the rangeland with bøur scenario, with these ranging from to 1496 - $1684 \mathrm{~kg}$ dry matter / ha, while seven hagi - partir see declines in vegetation productivity (ranging from $1105-1433 \mathrm{~kg}$ dry matter / ha). Of real significance however, is the decline in live body weights in all hagi - partir relative to the rangeland with bøur scenario $(73.0 \mathrm{~kg} / \mathrm{ha})$ with values ranging from $19.9-68.6 \mathrm{~kg} / \mathrm{ha}$ and utilisation rates stable or declining slightly. At Hov, five hagi-partir were introduced to the rangeland area, and in three of these vegetation productivity is improved while in two there is marginal decline under average conditions relative to productivity in the rangeland with bøur scenario (ranging from 1463$1755 \mathrm{~kg}$ dry matter / ha). Live body weights $(\mathrm{kg} / \mathrm{ha})$ range from $53.4-107.3$ with average conditions, a substantial increase in three of the five hagi - partir, and a marginal decline in the other two relative to the rangeland with bøur scenario $(58.5 \mathrm{~kg} / \mathrm{ka})$. Utilisation rates however also increase in all hagi - partir varying as an average from $29-38 \%$, indicating a greater grazing pressure on the landscape.

\section{Table IV located here}

The hagi - partir represent a significant change of grazing regime in Faroe and although grazing pressures were still within levels that were unlikely to contribute to land degradation we suggest that marked difference in landscape pressures and livestock productivities, and thus relative success of settlements, began to emerge as a result. In the more marginal area of Leirvík the introduction of the hagi - partir system at least stabilised and may have improved both vegetation and livestock 
body weight productivities while still ensuring that annual cumulative utilisation was kept to a level that did not damage rangeland productivity. Partitioning of the rangeland would have helped to ensured that in most cases there was appropriate distribution of livestock across the rangeland area and indicates that early rangeland management regimes could have improved pastures rather than simply cause their degradation. A similar situation emerges at Hov where the introduction of the hagi-partir system served to optimize utilisation rates, thus improving, or at least stabilizing, live body weights. In contrast, the decline in livestock productivity at Sandur suggests that the land may have been too finely divided to continue supporting the high levels of animal productivity evident during the earlier Norse period. Reasons for this over-fine rangeland division may have been due to the requirements of an emerging local population pressure in an area that was likely to have been generating surplus from rangelands since the early Norse period.

\section{CONCLUSIONS}

Modeled outputs from three contrasting rangeland areas in Faroe indicate that the maximum number of livestock rangeland areas could carry was low relative to carrying capacity at Landnám. We suggest therefore that grazing pressure was of itself insufficient to contribute to major and rapid change in vegetation cover and, agreeing with Humlum and Christiansen (1998), would not have contributed to historic soil erosion. We also suggest that carrying capacities indicated under the different growth scenarios of the model were such that they could accommodate any historic regional scale fluctuations in climate, which in any case is likely to have been limited within the Faroe archipelago (Turrell and Holliday, 2002). The low number of livestock relative to rangeland carrying capacity may also explain the demise of the shieling system in Faroe by the 1200's. Shieling, or seter, areas grazed by milking livestock in the summer months would have been brought to Faroe as part of the Norse land management cultural package a way of exploiting remoter pastures and saving other grazing and hay production areas for the winter period 
(Borchgrevink, 1977). Given that modeled evidence suggests sufficient biomass for the numbers of livestock likely to have been utilising the rangeland area, the shieling areas become of less importance. This is in marked contrast to Iceland where shieling use continued into the early modern period (Vésteinsson et al., 2002), and in the Eastern Settlement of Greenland where the shieling system may have survived until the demise of Norse settlement (Albrethsen \& Keller 1986).

The introduction of highly structured rangeland partitioning and regulation of livestock numbers, as indicated in Seyðabrcevið (the Sheep Letter) and implying refined and careful grazing management, is unlikely to have been a response to land degradation or as an attempt to minimise the landscape impacts of grazing. Rather, while ensuring that land resources were not over utilised, we see partitioning primarily as an attempt to ensure that the community as a whole had fair and agreed access to rangeland areas. In doing so, the reasons for organising and managing rangeland areas parallel those found in medieval and early modern northern England and its border with Scotland where complex and elaborate social arrangements governed the use of grazing resources on behalf of the user communities as a whole (Winchester, 2000). The benefits of this rangeland management strategy in Faroe were mixed however. More marginal rangelands increasing biomass and livestock productivity and some rangelands improving biomass utilisation rates; other rangeland areas that were too finely partitioned were likely to suffer substantial decline in livestock productivities. We thus see partitioning of rangeland as a contributor to long-term differentiation of landscapes and the relative success of settlements across Faroe beyond the Norse period. 


\section{ACKNOWLEDGEMENTS}

The authors gratefully acknowledge the support of the Leverhulme Trust through the Landscapes circum- Landnám programme. John MacArthur (University of Stirling) assisted with the modeling analyses and Bill Jamieson (University of Stirling) drew the figures. Paul Buckland provided valuable comment on an earlier draft of the paper. 


\section{REFERENCES}

Adderley, W.P. and Simpson, I.A. (in press). Early Norse home-field productivity in the Faroe islands. Human Ecology.

Albrethsen, S. E. and Keller, C. (1986). The use of the saeter in medieval Norse farming in Greenland. Arctic Anthropology 23: 91-109.

Arge, S.V. (1991). The Landnám in the Faroes. Arctic Anthropology 28: 101-120.

Arge, S.V. (1997). Í Uppistovubeitinum. Site and settlement. Fróðskaparrit 45: 27-44.

Arge, S. V. 2001. Forn búsetning heima á Sandi. Frødi 2, 5-13.

Arge, S., Sveinbjarnardóttir, G., Edwards, K.J., Buckland, P.C. and Simpson, I.A. (in press). Viking and medieval settlement in the Faroes. Human Ecology.

Borchgrevink, A.-B. Ø. (1977). The Seter areas of rural Norway. A traditional multi-purpose resource. Northern Studies 9: 3-24.

Brandt, J. (1984). Landscape ecological information through statistical analysis of the territorial structure of a sheep grazing system, Faroe Islands. In Brandt, J. and Agger, P. (eds.) Methodology in Landscape Ecological Research and Planning. Volume III: Theme III Methodology of Data Analysis. International Association of Landscape Ecology, Roskilde. 43-57.

Brandt, J. (1996). Sheep breeding on Eastern Sandoy. In Guttesen, R. (ed.) The Faeroe Islands Topographic Atlas. Det Kongelige Danske Geografiska Selskab and Kort \& Matrikelstyrelsen, København. 82-84.

Buckland, P.C., Dugmore, A.J., Perry, D., Savory, D. and Sveinbjarnardóttir, G. (1991). Holt in Eyjafjallasveit, Iceland: A palaeoecological study of the impact of Landnám. Acta Archaeologica 61: 267-271.

Dahl, S. (1970). The Norse settlement of the Faroe Islands. Medieval Archaeology 14: 60-73

Danish Meteorological Institute (1998). The Climate of the Faroe Islands - with Climatological Standard Normals, 1961-1990. DMI, Copenhagen. 
Edwards, K.J., Buckland, P.C., Craigie, R., Panagiotakopulu, E. and Stummann-Hansen, S. (1998). Landscapes at Landnám: Palynological evidence from Toftanes, Faroe Islands. Fróðskaparrit 46: 229-244.

Edwards, K.J., Borthwick, D., Cok, G., Dugmore, A. J., Mairs, K.-A., Church, M. J., Simpson, I. A. and Adderley, W.P. (in press). Landscape change in eastern Suðuroy, Faroe islands: A hypothesis-based approach to the determination of natural processes and human artifice. Human Ecology.

Fosaa, A.M. (2001). A review of plant communities of the Faroe Islands. Fróðskaparrit 48: 41-54.

Fredskild, B. (1988). Agriculture in a marginal area - South Greenland from the Norse Landnam (985 A.D.) to the present (1985 A.D.). In Birks, H., Birks H.J.B., Kaland, P.E. and Moe, D. (eds.) The Cultural Landscape Past, Present and Future. Cambridge University Press, Cambridge. 381-393.

Fredskild, B. (1992). Agriculture in SW Greenland in the Norse period (A.D. 982 - c. 1450). Journal of the European Network of Scientific Cooperation for Cultural Heritage 31: 39-43.

Friðriksson, S. (1972). Grass and grass utilisation in Iceland. Ecology 53: 785-796.

Hallsdóttir, M. (1987). Pollen analytical studies of human influence on vegetation in relation to the Landnám tephra layer in southwest Iceland. Lundqua Thesis 18, Department of Quaternary Geology, Lund University.

Hannon, G.E., Wastegård, Bradshaw, E. and Bradshaw, R.H.W. (2001). Human impacts and landscape degradation on the Faroe Islands. Proceedings of the Royal Irish Academy 101B: 129-139.

Hannon, G.E. and Bradshaw, R.H.W. (2000). Impacts and timing of the first human settlement on vegetation of the Faroe Islands. Quaternary Research 54: 404-413.

Hansen, K. and Johansen, J. (1982). Flora and vegetation of the Faroe Islands. Monographiae Biologicae 46: $35-52$.

Humlum, O. and Christiansen, H.H. (1998). Late Holocene climate forcing of geomorphic activity in the Faroe Islands. Fróðskaparrit 46: 169-189.

Jakobsen, B.H. (1991). Soil resources and soil erosion in the Norse settlement area of Østerbygden in southern Greenland. Acta Borealia 1: 56-68. 
Jóhansen, J. (1981). Vegetational development in the Faroes from 10,000 BP to the present. DGU Arbog 1981: 111-136.

Lawson, I.T., Edwards, K.J., Arge, S., Dugmore, A.J., Church, M., Mairss, K-A. and McGovern, T.H. (in press). Landscapes of southern Sandoy, Faroes, circum-landnám. Human Ecology.

Mahler, D. (1991). Argisbrekka. New evidence of shielings in the Faroe Islands. Acta Archaeologica 61: 6072.

Melsteð, B., Jónsson, F. and pórlófsson, B. (eds.) (1990). Jarðabók Árna Magnússonar og Páls Vídalín 1-11, Copenhagen.

RALA (1978a). Utilization and conservation of grasslands. Progress report 1976. Agricultural Research Institute, Iceland. RALA Report no. 29, Reykjavík.

RALA (1978b). Utilization and conservation of grasslands. Progress report 1977. Agricultural Research Institute, Iceland. RALA Report no. 38, Reykjavík.

RALA (1979). Utilization and conservation of grasslands. Progress report 1978. Agricultural Research Institute, Iceland. RALA Report no. 50, Reykjavík.

RALA (1980). Utilization and conservation of grasslands. Progress report 1979. Agricultural Research Institute, Iceland. RALA report no. 63, Reykjavík.

RALA (1981). Utilization and conservation of grasslands. Progress report 1980. Agricultural Research Institute, Iceland. RALA report no. 63, Reykjavík.

Sandgren, P. and Fredskild, B. (1991). Magnetic measurements recording Late Holocene man-induced erosion in S. Greenland. Boreas 20: 315-331.

Simpson, I.A., Dugmore, A.J., Thomson, A.M. and Vésteinsson, O. (2001). Crossing the thresholds: Human ecology and historical patterns of landscape degradation. Catena 42: 175-192. 
Simpson, I.A. and Guttmann, E.B. (2002). Transitions in early arable land management in the Northern Isles: the Papar as agricultural innovators? In B. Crawford (ed.) The Papar of the North Atlantic: Environment and History. St Andrews: St John's House papers No.10. pp 59-67.

Simpson, I.A., Guðmundsson, G., Thomson, A.M. and Cluett, J. (2004). Assessing the role of winter grazing in land degradation, Mývatnssveit, northeast Iceland. Geoarchaeology 19: 471-502.

Stummann Hansen, S. (1988). The Norse Landnam in the Faroe Islands in the light of recent excavations at Toftanes, Leirvik. Northern Studies 25: 58-84.

Thomson, A.M. (2003). A modeling approach to farm management and vegetation degradation in pre-modern Iceland. Unpublished PhD Theses, University of Stirling.

Thomson, A.M. and Simpson, I.A. (in press a). Modeling historic rangeland management and grazing pressures, Mývatnssveit Iceland. Human Ecology.

Thomson, A.M. and Simpson, I.A. (in press b). Modeling the impact of historical land management decisions in sensitive landscapes: The construction of a grazing model for Iceland. Environmental Modeling and Software.

Thorsteinsson, L., Olafsson, G. and van Dyke, G.M. (1971). Range resources of Iceland. Journal of Range Management 48: 350-357.

Tierney, J.J (ed.) (1967). Dicuilus. Liber de Mensura Orbis Terrae. Scriptores Latini Hiberniai 6 (Dublin).

Turrell, W. and Holliday, N.P. (2002). The Annual ICES Ocean Climate Status Summary 2001.2002. International Council for the Exploration of the Sea, Copenhagen.

Vésteinsson, O., McGovern, T.H. and Keller, C. (2002) Enduring impacts: Social and environmental aspects of Viking Age settlement in Iceland and Greenland. Archaeologia Islandica 2: 98-136.

Vickers, K., Bending, J., Buckland, P.C., Edwards, K.J. and Stummann-Hansen, S. (in press). Toftanes: The palaeoecology of a Faroese landnám farm. Human Ecology 
Winchester, A.J.L. (2000). The Harvest of the Hills. Rural Life in Northern England and the Scottish Borders, 1400-1700. Edinburgh University Press, Edinburgh. 


\section{LIST OF FIGURES AND TABLES}

Figure 1: Location of Faroe and the North Atlantic region; location of Leirvík, Sandur and Hov study sites.

Figure 2: Structure diagram of Búmodel (Thomson and Simpson, in press b).

Figure 3: Modeled v. measured utilisable biomass values for five sample points, Sandur, Faroe.

Figure 4: Example modeled rangeland analyses for Leirvík; a) reconstructed vegetation cover at Landnám with enclosed homefield; b) predicted average annual utilisable biomass distribution (dry matter $\mathrm{kg} / \mathrm{ha}$ ) with onset of grazing at Landnám; c) annual cumulative utilisation distribution (\%) with onset of grazing at Landnám.

Figure 5: Example modeled rangeland analyses for Sandur; a) reconstructed vegetation cover at Landnám; b) predicted average annual utilisable biomass (dry matter $\mathrm{kg} / \mathrm{ha}$ ) with onset of grazing at Landnám; c) predicted annual cumulative utlisation distribution (\%) with onset of grazing at Landnám.

Figure 6: Modeled rangeland analyses for Hov; a) reconstructed vegetation cover at Landnám; b) predicted average annual utilisable biomass distribution (dry matter $\mathrm{kg} / \mathrm{ha}$ ) with onset of grazing at Landnám; c) annual cumulative utilisation distribution (\%) with onset of grazing at Landnám.

Table I: Búmodel growth scenarios for Faroe (based on Thomson, 2003).

Table II: Management types considered in Búmodel simulations.

Table III: Búmodel output indicators of carrying capacities and rangeland utilisation efficiencies for Leirvík, Sandur and Hov.

Table IV: Summary Búmodel output indicators of hagi - partir grazing areas under average growth conditions. 


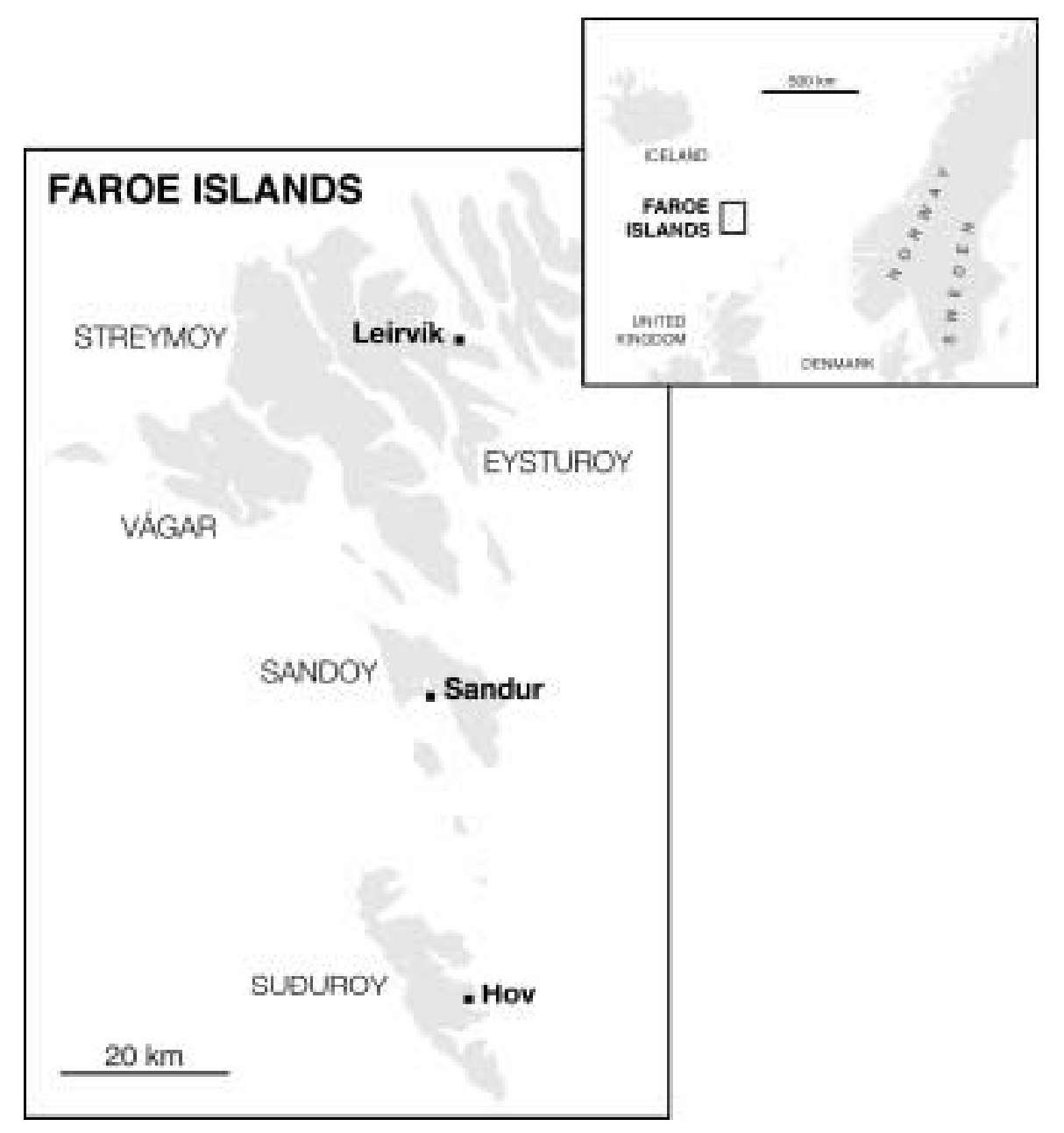

Figure 1 


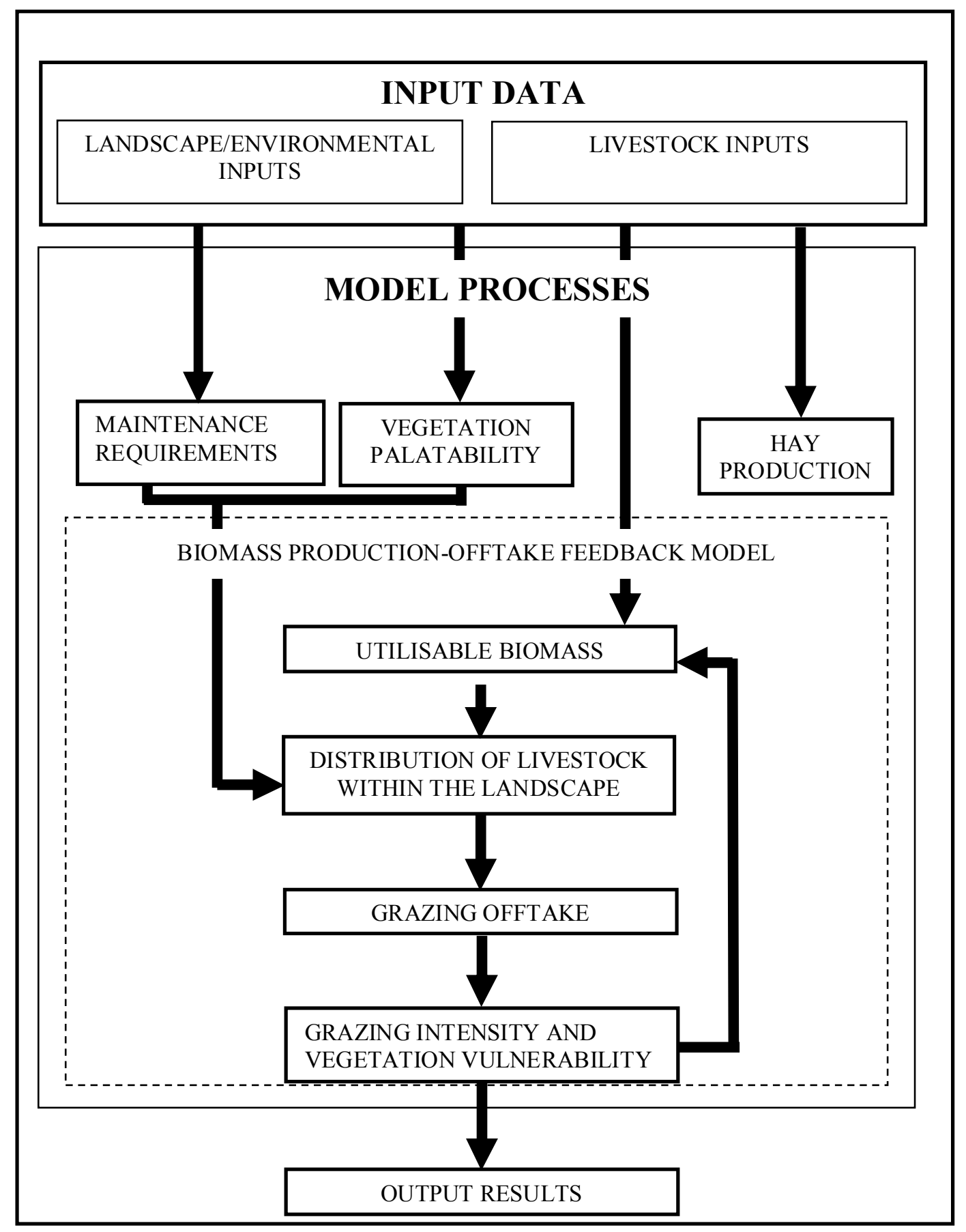

Figure 2 


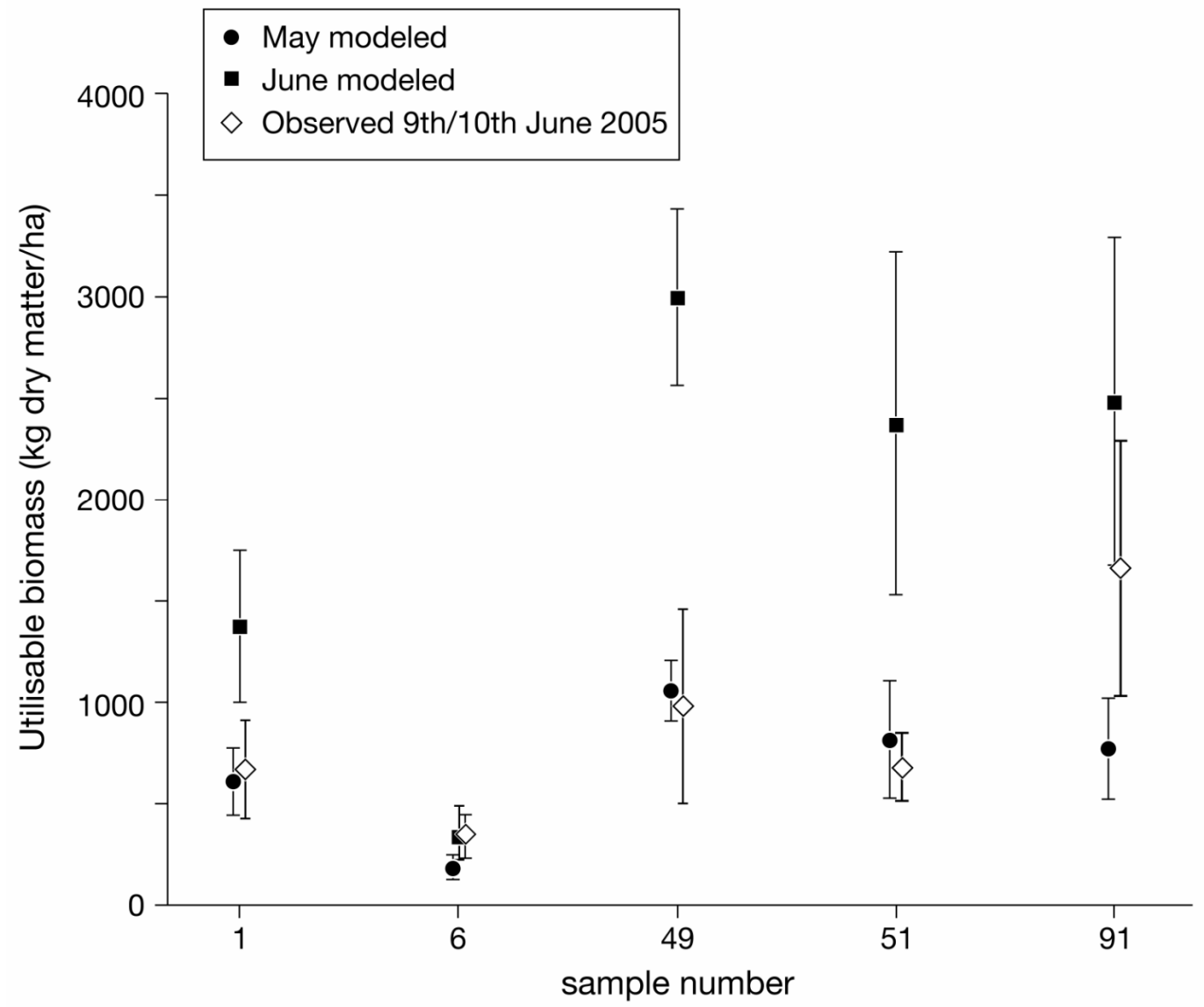

Figure 3 

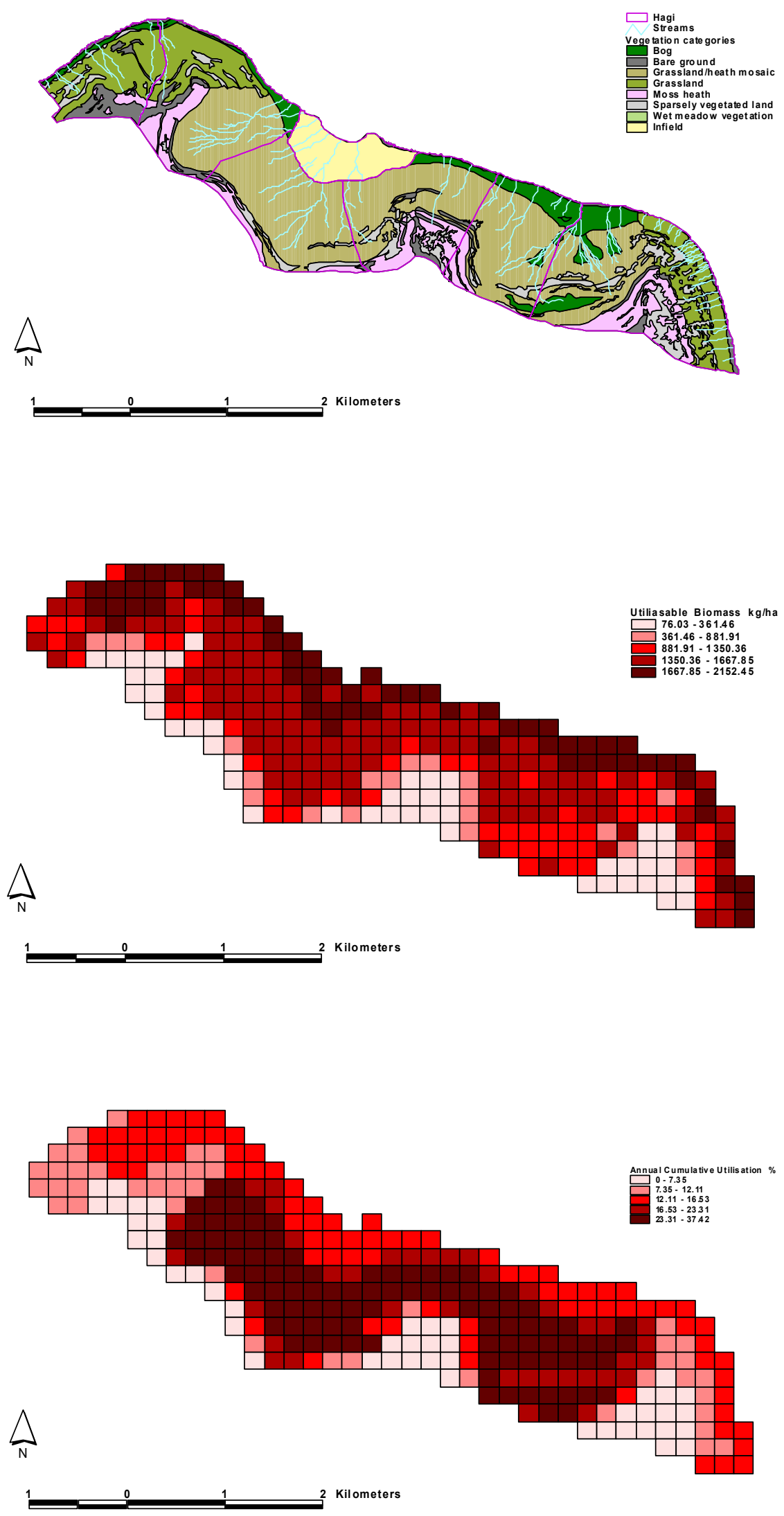

Figure 4 


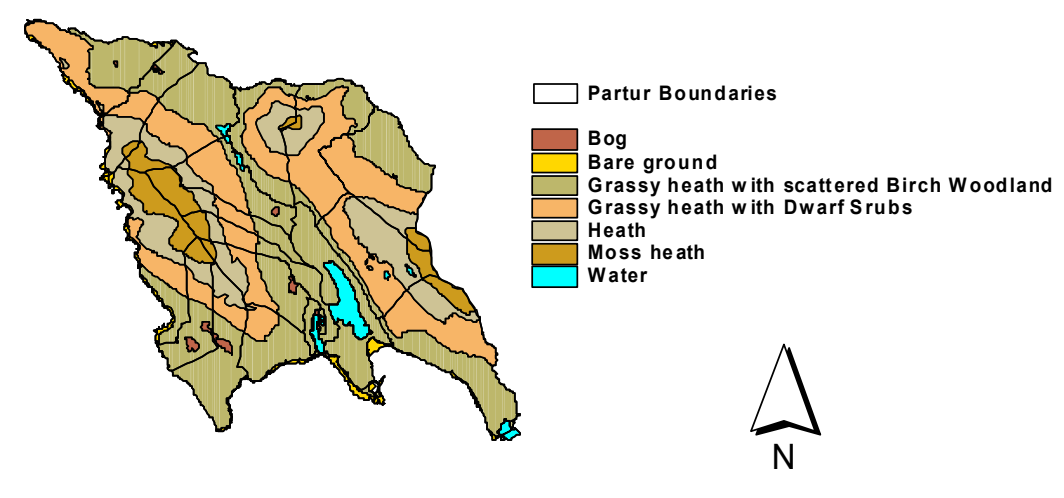
$\underbrace{8 \text { Kilometers }}$
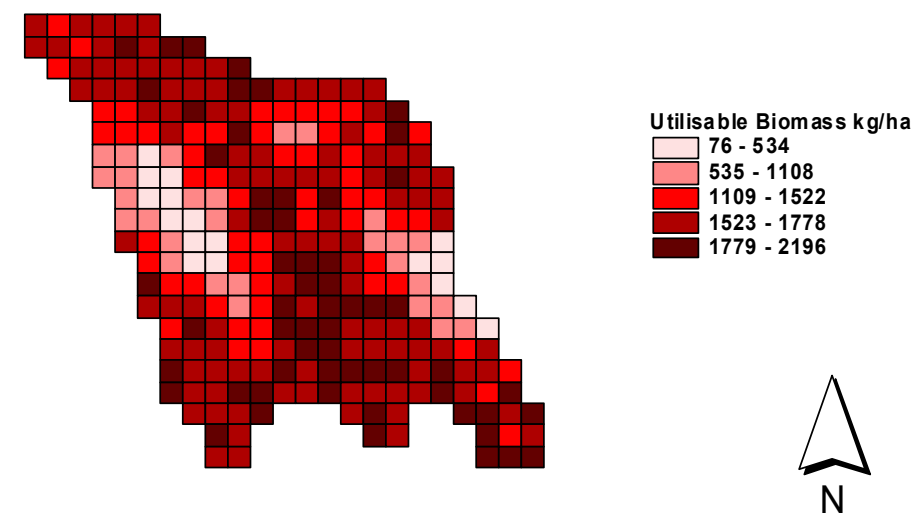

6 Kilometers

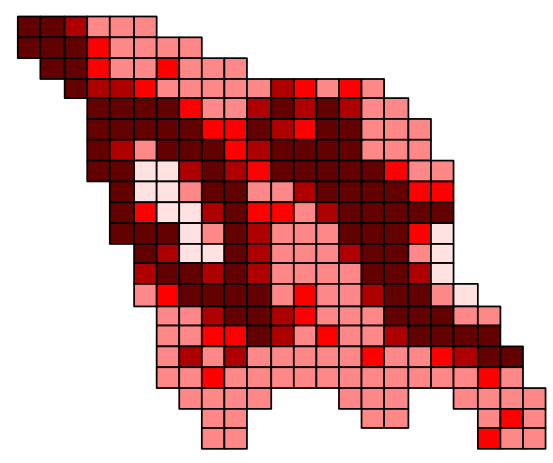

An nual Cumulative Utilisation \%

$8.25-17.6$

$8.25-17.6$
$17.6-28.05$

$28.05-31.96$

$31.96-36.19$

$36.19-40.61$

Figure 5 

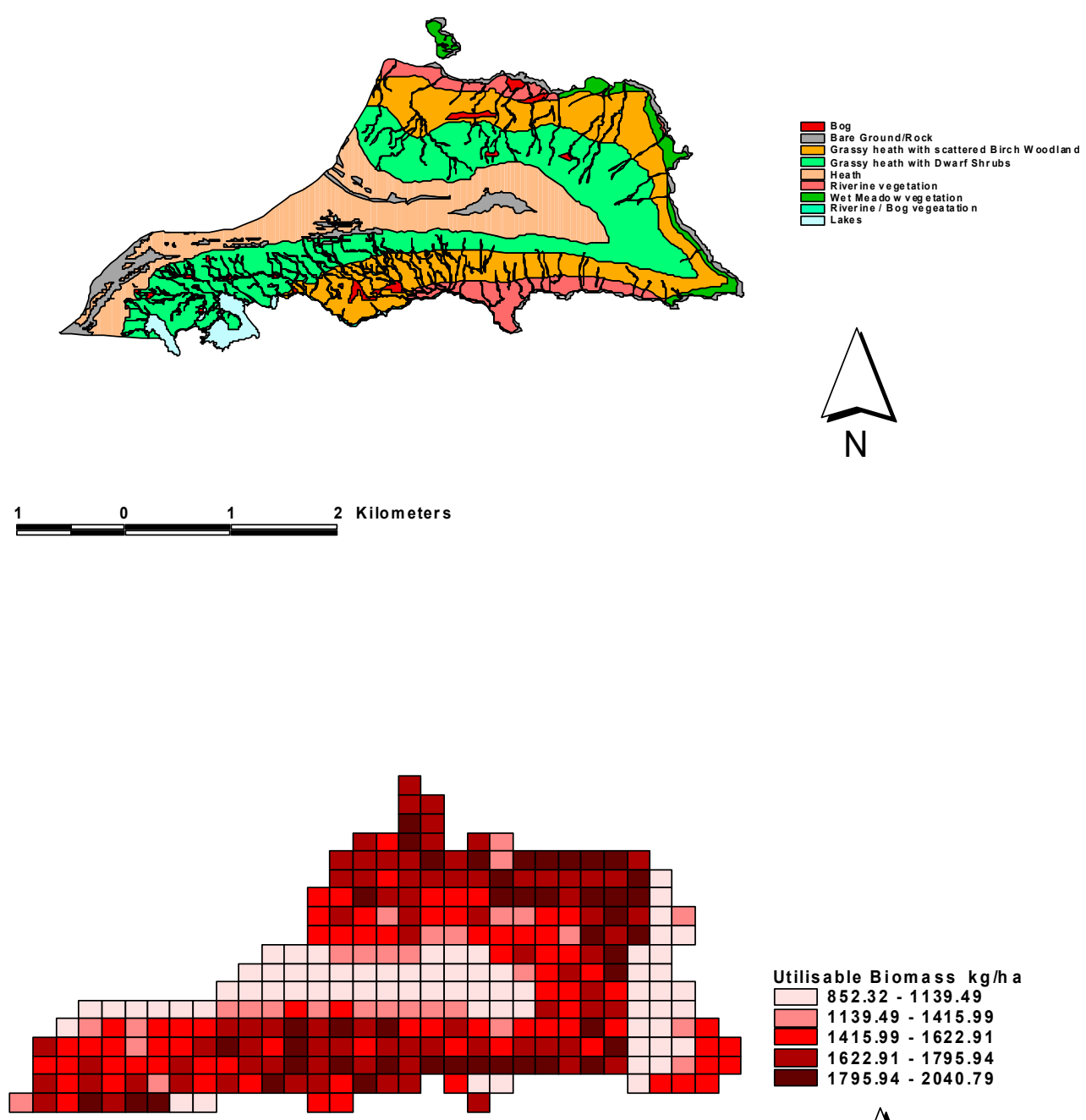

Utilisable Biomass $\mathrm{kg} / \mathrm{h}$
\begin{tabular}{|c}
$852.32-1139.49$ \\
$1139.49-1415.99$ \\
$1415.99-1622.91$ \\
$1622.91-1795.94$ \\
$1795.94-2040.79$
\end{tabular}

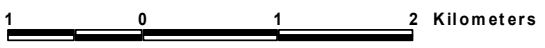

$\Delta$

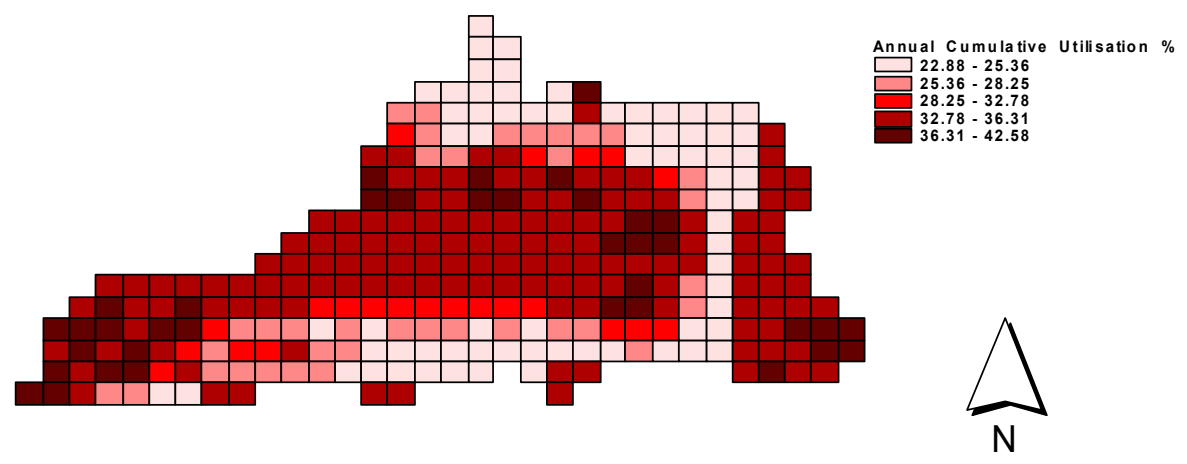

Figure 6

2 Kilometers 


\begin{tabular}{c|cccc}
\hline $\begin{array}{c}\text { Growth } \\
\text { scenario }\end{array}$ & Growing season & $\begin{array}{c}\text { Time of peak } \\
\text { biomass }\end{array}$ & $\begin{array}{c}\text { Mean } \\
\text { temperature } \\
\text { May-September }\end{array}$ & $\begin{array}{c}\text { Relative } \\
\text { biomass } \\
\text { production }\end{array}$ \\
\hline Good & May-October & July & 10.2 & $130 \%$ \\
Average & May-September & July & 9.0 & $100 \%$ \\
Poor & June-September & August & 8.5 & $60 \%$ \\
\hline
\end{tabular}

\section{Table I}




\begin{tabular}{l|l}
\hline Management types & Description \\
\hline Pre - Landnám & $\begin{array}{l}\text { No grazing. The landscape immediately prior to Landnám } \\
\text { No grazing controls. All livestock have access to all areas at } \\
\text { all times, except for shieling areas }\end{array}$ \\
Open Rangeland & $\begin{array}{l}\text { Bøur areas are enclosed. No division of the rangeland except } \\
\text { for shieling areas }\end{array}$ \\
Hagi Rangeland & Rangeland is divided into hagi pastures; no shieling areas \\
\hline
\end{tabular}

\section{Table II}




\begin{tabular}{|c|c|c|c|c|c|c|c|c|c|c|}
\hline & & Leirvík & & & Hov & & & Sandur & & \\
\hline & & $\begin{array}{l}\text { Pre- } \\
\text { Landnám }\end{array}$ & Landnám & $\begin{array}{l}\text { Landnám } \\
\text { with } \\
\text { Bøur }\end{array}$ & $\begin{array}{l}\text { Pre- } \\
\text { Landnám }\end{array}$ & Landnám & $\begin{array}{l}\text { Landnám } \\
\text { with } \\
\text { Bøur }\end{array}$ & $\begin{array}{l}\text { Pre- } \\
\text { Landnám }\end{array}$ & Landnám & $\begin{array}{l}\text { Landnám } \\
\text { with } \\
\text { Bøur }\end{array}$ \\
\hline \multirow{4}{*}{$\begin{array}{l}\text { Average } \\
\text { growth } \\
\text { conditions }\end{array}$} & $\begin{array}{l}\text { Maximum ewe } \\
\text { and lamb / ha }\end{array}$ & - & 0.8 & 0.55 & - & 1.3 & 1.2 & - & 1.4 & 1.3 \\
\hline & $\begin{array}{l}\text { Live body } \\
\text { weight }(\mathrm{kg} / \mathrm{ha})\end{array}$ & - & 28.2 & 18.7 & - & 63.4 & 58.5 & - & 72.3 & 73.0 \\
\hline & $\begin{array}{l}\text { Utilisable } \\
\text { biomass } \quad(\mathrm{kg} \\
\mathrm{dm} / \mathrm{ha})\end{array}$ & 1290 & 1245 & 1182 & 1570 & 1486 & 1497 & 1575 & 1484 & 1473 \\
\hline & $\begin{array}{l}\% \text { annual } \\
\text { cumulative } \\
\text { utilisation }\end{array}$ & - & 17 & 14 & - & 32 & 29 & - & 31 & 32 \\
\hline \multirow{4}{*}{$\begin{array}{l}\text { Good } \\
\text { growth } \\
\text { conditions }\end{array}$} & $\begin{array}{l}\text { Maximum ewe } \\
\text { and lamb / ha }\end{array}$ & - & 1.25 & 0.9 & - & 1.6 & 1.4 & - & 1.8 & 1.8 \\
\hline & $\begin{array}{l}\text { Live body } \\
\text { weight }(\mathrm{kg} / \mathrm{ha})\end{array}$ & - & - & - & - & 78.2 & 61.2 & - & 90.6 & 97.2 \\
\hline & $\begin{array}{l}\text { Utilisable } \\
\text { Biomass } \quad(\mathrm{kg} \\
\mathrm{dm} / \mathrm{ha})\end{array}$ & 1556 & 1495 & 1419 & 1980 & 1803 & 1782 & 1880 & 1790 & 1770 \\
\hline & $\begin{array}{l}\% \quad \text { annual } \\
\text { cumulative } \\
\text { utilisation }\end{array}$ & - & 18 & 15 & - & 26 & 22 & - & 26 & 31 \\
\hline \multirow{4}{*}{$\begin{array}{l}\text { Poor } \\
\text { growth } \\
\text { conditions }\end{array}$} & $\begin{array}{l}\text { Maximum ewe } \\
\text { and lamb / ha }\end{array}$ & - & 0.55 & 0.4 & - & 0.75 & 0.6 & - & 0.75 & 0.7 \\
\hline & $\begin{array}{l}\text { Live body } \\
\text { weight }(\mathrm{kg} / \mathrm{ha})\end{array}$ & - & - & - & & 34.5 & 28.4 & - & 41.6 & 40.14 \\
\hline & $\begin{array}{l}\text { Utilisable } \\
\text { biomass } \\
\mathrm{dm} / \mathrm{ha})\end{array}$ & 1012 & 982 & 924 & 1224 & 1177 & 1021 & 1196 & 1135 & 1122.85 \\
\hline & $\begin{array}{l}\% \quad \text { annual } \\
\text { cumulative } \\
\text { utilisation }\end{array}$ & - & 18 & 18 & - & 27 & 23 & - & 31 & 30.73 \\
\hline
\end{tabular}

Table III 


\begin{tabular}{|l|l|l|l|l|}
\hline & $\begin{array}{l}\text { Number of Hagi-partir } \\
\text { areas }\end{array}$ & $\begin{array}{l}\text { Live body weight } \\
\text { range (kg/ha) }\end{array}$ & $\begin{array}{l}\text { Utilisable biomass } \\
\text { range (DM kg/ha) }\end{array}$ & $\begin{array}{l}\text { \% Annual cumulative } \\
\text { utilisation }\end{array}$ \\
\hline Leirvík & 6 & $22.6-28.5$ & $1093-1215$ & $12-21$ \\
\hline Sandur & 16 & $19.9-60.3$ & $1106-1685$ & $18-34$ \\
\hline Hov & 5 & $53-107$ & $1463-1755$ & $29-38$ \\
\hline
\end{tabular}

\section{Table IV}




\section{Sustainable Rangeland Grazing in Norse Faroe}

\section{Amanda M. Thomson", Ian A. Simpson², Jennifer L. Brown}

The introduction of domestic livestock - particularly sheep - and rangeland grazing by Norse settlers to Faroe during the $9^{\text {th }}$ century has generally been described as a major pressure on a sensitive landscape, leading to rapid and widespread vegetation change and contributing to land degradation. This view has, however, been developed without consideration of Norse grazing management practices which may have served to minimise grazing impacts on landscapes as well as sustaining and enhancing vegetation and livestock productivity. These alternative scenarios are considered using a historical grazing management simulation model with Faroese climate and vegetation inputs and given archaeological, historical and palaeo-environmental parameters. Three contrasting rangeland areas are investigated and, based on the maximum number of ewe / lamb pairs the rangeland could sustain, modeling suggests that utilisable biomass declined with the onset of grazing activity, but not to a level that would cause major changes in vegetation cover or contribute to soil erosion even under climatically determined poor growth conditions. When rangeland areas partitioned into what are termed hagi and partir are modeled, grazing levels are still within rangeland carrying capacities, but productivities are variable. Some rangeland areas increase biomass and livestock productivity's and biomass utilisation rates while other rangeland areas that were too finely partitioned were likely to suffer substantial decline in livestock productivities. Partitioning of rangeland is a likely contributor to long-term differentiation of landscapes and the relative success of settlements across Faroe beyond the Norse period.

Key Words: Historical ecology; modeling; rangeland management; Norse Faroe. 


\section{Manuscript HUEC66 \\ Sustainable rangeland grazing in Norse Faroe}

\section{Corresponding author: Ian A. Simpson \\ i.a.simpson@stirling.ac.uk}

\section{Response to reviewer's comments}

We appreciate the constructive comments from reviewer's; our response is give below. We have also improved the paper by -

a) integrating new (in press) pollen data to support vegetation reconstructions, accuracy assessment of vegetation maps and field verification of modelled productivities.

b) adding analyses of one additional grazing area, giving greater security to the interpretations made.

c) referencing the papers in the recent Human Ecology part/volume on Faroes.

\section{Reviewer \#1:}

The date 'c. 825' suggests more accurate knowledge of the dating of the settlement of the Faroes than actually exists. The archaeological evidence at present does not allow a closer dating than the 9 th century.

$<$ ca. AD 825 date removed and $9^{\text {th }}$ century used throughout paper.

Page 3. The definition 'colonisation and settlement of Faroe (ca. AD-825-AD 1300)' seems to imply that the settlement phase went on into the 13th century - which it did not as far as can be seen. One could talk of the Viking age and high medieval period in the Faroes

$<$ the suggested modification of the text has been made.

Page 4 and elsewhere. Talk about partitioning the rangeland into hagi areas does not sound well informed - and these practices certainly only have early-modern evidence to support them, which might be made clear. Although an attempt is made on p. 5 to define this it is not made clear that the rangeland is divided into hagar, each hagi belonging to one bygð/bour, and in turn divided into partir, one (or more?) for each býlingur. These divisions of the rangeland were maintained not by any physical boundaries, fences or walls, but by shepherding which makes their application to medieval conditions at best optimistic.

$<$ this section has been revised in line with reviewer comments; we still hold the view that the late Norse / medieval Sheep Letter is indicating partitioning of the rangeland areas, but acknowledge in the text that the only clear evidence for rangeland partitioning is from the early modern period. 
Page 7. Syntactically there is something wrong with the sentence "The pre-modern settlement ... composed one or several farming units, often with a church." Semantically it is also not clear enough. The enclosed townships, the bøur referred to later (also called bygðir), consisted of one or more býlingar, (and note that ca. half of the bygðir only had one býlingur), farms (I don't think you need to say 'old' here - it is implied in the term fyrndarbýlingur, but is really unknowable) who could in turn be divided into several households. The churches are never more than one to bygð/bøur and I would think they were associated with the býlingur rather than individual households.

$<$ the sentence has been revised in line with reviewer comment

Page 7. 'partur (sing. partir)' surely this is supposed to be 'partur (plur. partir)' ?

$<$ as given in the text

Page 7. 'agricultural law' - it is not possible to say that this had the force of law, 'regulations' would be more apt

$<$ sentence revised

Page 7. 'skipan' I don't have my Faroese dictionary with me, but skipan surely means just 'arrangement' and not the very specialised meaning implied here. I am not convinced about the contrast between the earlier skipan and later marketal, neither the historicity of it nor that there is any contrast. The marketal refers to the assessment of the farms, proportions of the total assessment of the bygd/bøur. In recent centuries the numbers of livestock grazed in the hagi by each farm was in proportion to its share of the total value of the bygð. So that a farm valued at $20 \%$ of the bygð could graze $20 \%$ of the livestock put on the hagi. Just as Seyðabréfið implies, the total number was the crucial issue, and the marketal on its own could not be used to figure that out. For that some more subjective method was called for - presumably common agreement among the farmers as with the Icelandic ítala.

$<$ the statements in the text are qualified and discussion of relationship of skipan to marketal removed

Page 9. To be safe I'd say that Færeyinga saga was written after 1200 AD

$<$ revised in line with reviewer comment

Page 9. 'medieval period' - needs definition in this context

$<$ clarification given, based on Jóhansen (1981)

Page 18. The shielings are a crucial issue in this context, and one that needs to be considered earlier in the paper and more sensibly. The fact that there were shielings in Viking age Faroes suggests a radically different management of the pastures than in later 
times - presumably more intesive and more directed towards cattle dairy production. This is not taken into account in the modeling and makes it less valuable as a result. The sentence 'Given that modeled evidence suggests ... the shieling areas become of less importance.' only makes sense if you think that the shielings represent only timewasting on the part of the Faroese farmers, not significantly more intensive (i.e. more livestock and more biomass offtake) farming.

$<$ Outline of the shieling system is now incorporated into the Historical Ecology Context section of the paper, and shieling sites within the study areas are identified. The issue of shielings is embedded in the Results and Discussion and in the Conclusions.

\section{Reviewer \#3:}

The application of a grazing model to the Faroes to assess the potential impact of grazing in the past is a potentially valuable exercise. However when working in the past a number of key variables are poorly known and this paper considers a rather restricted range of past scenarios. The failure to address likely climatic differences between the past and present, the failure to cite dating evidence for the onset of grazing, the failure to consider other physical impacts of grazing such as hoof damage and subsequent erosion, the failure to consider goats and the use of a model that is as yet unavailable for study by this referee makes this a weak contribution. The discussion centres around sheep, but what about goats, which affect vegetation in a different and unmodelled manner?

$<$ Climatic differences are already explicitly embedded in the analyses and paper through consideration of three growth scenarios - good, average and poor. Dating of settlement / grazing onset has been clarified in various sections of the paper, emphasising that we are considering Norse settlement from Viking (early Norse) to the Medieval (late Norse). Evidence for earlier settlement is disputed, largely because of the problems of securing accurate radiocarbon dating evidence within mobile landscapes and the absence of corroborative archaeological evidence. Goats are a very minor component in the available zoo-archaeological evidence and therefore not considered in this paper. The integration of grazing pressures - modelled in this paper - and erosion characteristics in the landscape will be considered in a future paper; this is emphasised in the conclusions, although the submitted paper identified references suggesting that grazing pressure would not have contributed to soil erosion. The model is now available with the www address given in the text: http://www.sbes.stir.ac.uk/research/environmental_modelling/. (We are in the process of putting the documentation together and this will be completed before publication).

\section{Specific points:-}

Abstract. The introduction of domestic livestock is stated as dating from AD 825. Yet goat/sheep bones from the Faroes have been dated to AD 662 (I-16535). 
$<$ precise year removed and replaced with $9^{\text {th }}$ century. See comments on earlier ates above.

p.2 what are "historic numbers of livestock"?

$<$ changed to 'defined in historical documentary sources'

p.3 settlement dates on the Faroes are the subject of debate. Justification needed for the AD 825 date and explanation of published earlier dates of settlement activities (e.g. cereal cultivation).

$<$ AD 825 date changes to $9^{\text {th }}$ century; evidence of earlier settlement activity fully acknowledged while recognising the disputed nature of this evidence (see above).

p.5 reference to debate about earlier settlement. A more thorough evaluation is needed, including citing dates.

$<$ Evidence of earlier settlement activity fully acknowledged while recognising the disputed nature of this evidence (see above).

p.6 incomplete reference.

$<$ modified

p.7 Details of the model are needed. It is insufficient to cite material that is not yet available. Winter conditions are likely to be critical, how does the model handle seasonality? Is only removal of vegetation by grazing considered. What about physical damage from hooves and onset of micro-erosion. This has been shown to be a key process in related environments.

$<$ The model is now available with the www address given in the text: http://www.sbes.stir.ac.uk/research/environmental modelling/. (We are in the process of putting the documentation together and this will be completed before publication). The submitted text explicitly states that the model '... predicts patterns....on a monthly basis..'; it therefore incorporates seasonality. Feedback loops within the model, indicated in Figure 2, incorporates relationships between grazing intensity and vegetation vulnerability to utilisable biomass.

p.8 Present climate is not entirely relevant for this study. Some estimates of past climatic variables are needed, particularly to capture the onset of the Little Ice Age.

$<$ This again is explicitly acknowledged in the paper with the use of three climatic scenarios (good, average, poor). The LIA is, arguably, outside our time frame.

p. 8 There is a built-in assumption that sheep are the only relevant livestock. What about goats etc? 
$<$ Goats are a very minor component in the available zoo-archaeological evidence and therefore not considered in this paper.

p.13 Are sheep population estimates based on 30-50 per household? This could be a severe underestimate if sheep were placed on the islands prior to formal settlement and allowed to roam free. A population growth model and related impact of this scenario would be interesting.

$<$ There is a misunderstanding here; sheep numbers reported in the results and discussion section are derived from rangeland carrying capacities, as defined by the model analyses, not the estimated number of households.

p.14 I do not feel the key hypothesis is adequately tested by the limited range of scenarios applied here. Failure to consider past climates, other species, earlier introduction make this paper unsatisfactory.

$<$ these issues are dealt with above.

\section{Reviewer \#4:}

This is a well written and clearly developed paper that applies a series of modeling approaches already well developed for Icelandic and Scottish cases to the Faroes. The results are clearly and concisely reported, and the overall paper is very strong. I suggest publication without alteration. Fine work. 